\title{
成人期における他者視点（子ども，配偶者，両親，友人，職場の人）の 理想一現実自己のズレが自尊感情に及ぼす影響
}

—性役割観との関連から—

$\begin{array}{lllllllll}\text { 松 岡 弥 玲* } & \text { 加 藤 美 和** } & \text { 神 } \text { 戸 美 香** } & \text { 澤 本 陽 子** } \\ \text { 菅 野 真智子** } & \text { 詫 間 里嘉子** 野 瀬 } & \text { 早 織*** } & \text { 森 } & \text { ゆき絵** }\end{array}$

本研究では, 成人期を対象に, 複数の他者(子ども, 配偶者, 両親, 友人, 職場の人) から望まれている自己 (他者視点の理想自己) と現実自己のズレが自尊感情に及ほす影響について, 性, 性役割観, 世代, 就業形 態との関連から検討した。調查参加者は就学前もしくは大学生の子どもを持つ成人期(子育て期, 巣立ち期) の男女計 404 名。自尊感情を基準変数，5つの他者視点の理想一現実自己のズレを説明変数とした重回 帰分析を行った結果, 際立った性差がみられ, 全体的に男性は職場のみ, 女性は複数の他者 (子ども, 友 人, 両親のうち 2 者)の視点からの理想一現実自己のズレが自尊感情に影響していた。また, 性役割観の違 いによってどの他者視点から影響を受けるのかが異なり, 子育て期の男性では伝統主義の場合は職場が 影響していたが, 平等主義群では子どもが影響していた。女性においては性役割観の違いが両親と友人 の影響の差として現れ，世代差は子どもと職場の影響の違いにみられた。就業形態別では，専業主婦は 両親のみが影響していた。以上のことから他者視点の理想一現実自己のズレが自尊感情に及ほす影響は 性，性役割観，世代，就業形態によって異なることが示された。

キーワード : 他者視点の理想一現実自己のズレ, 成人期, 性役割観, 性差, 世代差

\section{問 題}

理想自己は,「こうでありたい」という個人の自己の 方向性を示す自己概念である。理想自己は，個人の内 的な基準として現実自己と照らし合わされ, 両者のズ レは自己評価を規定する。

理想自己の研究には青年期を対象としたものが多く, それ以降の成人期や老年期を対象にしたものは数が少 ない。しかしながら, 松岡 (2006) では, 青年期から老 年期まで一貫して理想自己が自己の内的な基準として 機能し, 自尊感情と関わっており，この概念が人の生 涯に渡る適応を捉える上で有益であることが示された。 近年, 成人期の自殺率, うつ病の増加等が問題となっ ており (山田, 2004)，この時期の個人は自己の方向性を 見出すことに困難さを感じていることが指摘されてい る(岡本, 1997)。松岡 (2006) では, 理想自己の実現可能 性が成人期中期において減少し, その後回復する傾向

\footnotetext{
* 名古屋大学大学院教育発達科学研究科

テ464-8601 名古屋市千種区不老町

** 名古屋大学教育学部

*** 富山大学医学部
}

がみられた。青年期と老年期の間にある成人期はそれ までの生き方を問い直し, その後の人生の方向性を定 める重要な転換期である。そのため本研究では, 個人 の方向性に関わる概念である理想自己について, 特に 成人期を取り上げて検討する。

成人期は生物学的, 心理学的, 社会学的に大きく変 化する時期である。成人期にある個人は, 就職, 結婚, 出産など, この時期特有のイベントを経験する中で社 会や家庭で中心的な存在となり, 複数の重要な役割を 次々と担うようになる。同時に存在する複数の役割の 中で，自分なりの方向性をどう見出していくのかとい うことが成人期における適応を考える上で必要である。

Higgins（1987）は理想自己には自分自身がこうであ りたいという自己視点のものと, 他者が自分にはこう であって欲しいと望んでいるであろうという，他者視 点のものがあるとした。個人にとって重要な他者であ る場合，その他者からの視点も自己視点と同様に，現 実自己をそれに近づけようとする自己指針として機能 し，それぞれの理想自己 (当為自己も同様) と現実自己と が乘離している場合，否定的な感情が引き起こされる。 さきに述べたように，成人期の個人は，社会や家庭 において複数の他者と関わり，重要な役割を持つ。関 
わる他者との関係が異なれば，呈示しょうとする自己 の側面は異なり (福島, 2003 ; Reid \& Deaux, 1996), 複数 の異なった側面を持つ他者視点の理想自己が存在する ことになる(例えば,子どもから望まれる親としての側面, 配偶 者から望まれる夫または妻としての側面など)。従来の多重役 割研究において, 個人の主観的幸福感 (well-being)に影 響するのは，役割の数よりも役割の経験の質であるこ とが指摘されている（Helson, Elliot, \& Leigh, 1990 ; 太田 2000)。ある他者から望まれている自己と現実自己との ズレは，それぞれの役割をどれくらいこなせているか を示す指標として用いることができ，成人期の適応を 考える上で有効と考えられる。Higgins， Klein，\& Strauman(1985)の研究では, 最も重要な他者を選択さ せる方法によって他者視点の理想一現実自己のズレを 扱っている。しかしながら, 成人期の個人は, 複数の 他者から異なった側面の自己を同時に求められると考 えられ，一人の他者だけを取り上げるのでは十分では ない。ゆえに本研究では, 複数の他者視点の理想一現 実自己のズレを扱う。

また，本研究では適応の指標として自尊感情を取り 上げる。自尊感情は自分自身を基本的には価値あるも のとする感覚であり, 生きていく上での心理的な土台 として不可欠なものである(梶田, 1988)。自尊感情は従 来の理想自己の研究において, 理想自己が自己の内的 な基準として機能しているかどうかの指標としても用 いられてきた（遠藤, 1992 ; 水間, 1998 ; 松岡, 2006)。この自 尊感情は, 自己概念に含まれる情報の評価であり, ど の側面の自己概念によって自尊感情が支えられるのか には個人差がある（梶田, $1988 ;$ 山本・松井・山成, 1982 ; 遠 藤・井上・闌, 1992)。複数の役割は，それぞれ異なった自 己概念の側面を持つと考えられる。どの他者視点の理 想一現実自己のズレが自尊感情に影響するのかについ て検討することは, 複数の他者のうちどの他者から求 められる側面が成人期の個人の適応に影響を与えるの かを知る一つの手がかりとなると思われる。

では, どの他者視点の理想一現実自己のズレが自尊 感情に影響するのか。以下に述べる従来の研究から考 えると,これには性差があると推測される。

従来から，男性は職業役割を重視しがちであるが, 女性は複数の役割を重視するとされてきたが(柏木, 2003 ; 前川・無藤・野村・園田, 1996) この傾向には, 以下 の 2 点が影響していると考えられる。

まず, 伝統的性役割観の影響である。成人期は子ど もができることで性別役割分業が成立し（柏木，2003）, 青年期と比較してょり伝統的であるとされる（塚田,
2000 ; 稲毛, 1996)。女性の社会進出が増えた後も伝統的 性役割観がいまだ根強く, 男性は仕事を，女性は仕事 と家庭の両方を重視する状況になっていることが指摘 されている(柏木, 2003)。

次に, 男性と女性ではライフサイクルにおいて重視 される側面が異なるという点 (Josselson, 1973 ; 杉村, 1999 ; 伊藤, 1999）も，この結果に関連していると思われ る。従来から, 男性は個としての自律や達成を重視し, 女性は他者との親和を求める関係性を重視するといわ れてきた。これは，男性が他者を重視していないかの ように捉えられてきたが，近年は男性にとっても他者 との関係性は女性と同様に重要であり，その程度や質 が異なる(例えば, 男性は他者との関係の中でも達成や競争を求 め, 女性は愛着や親和を求める)いう見方がされている(杉村, 1999)。職場での関係性はノルマや昇進など家庭や両 親，友人との関係性と比較すると課題の達成に関わる ことが多いため, 男性への影響力が大きく，一方女性 は, 他者との親和的な関係を重要視するため, 職場・ 家庭などそれぞれの他者から同程度に影響をうけるの ではないかと考えられる。小川 (2003) では, 過去一年 間で最もつらくて苦しかった出来事を挙げさせており， それによると男性は家庭の問題よりも仕事上の出来事 をよりストレスフルだと感じる割合が高く，仕事量や それに伴う過労が大きなストレスになっているのに対 し，女性は，自分の家族の問題をストレスと感じてお り，仕事に関しても，仕事そのものより同僚との関係 といった仕事に伴う人間関係を多く挙げる傾向がみら れている。

このように, 伝統的性役割観と関係性において重要 視される側面に性差があることによって, 男性は達成 や自己実現と関わる職業役割を重視するが，女性は自 分がもつ複数の役割を重視すると思われる。従って, 他者視点の理想一現実自己のズレが自尊感情に与える 影響には性差があり, 男性は職場の人が望む理想一現 実自己のズレが自尊感情に影響するが，女性は複数の 他者が望む理想一現実自己のズレが自尊感情に影響す るのではないか, と考えられる。

しかしながら，一般的にはいまだに伝統的性役割観 が根強いとはいっても, 平等主義的な性役割観を持つ 男女も存在する。男性は職業役割, 女性は複数役割を 重視するという傾向は, さきに述べたように，伝統的 性役割観が反映された結果であると考えられ, 価値観 が異なれば, 違った結果になる可能性がある。Banikiotes, Neimeyer, \& Lepkowsky (1981), Donaghue \& Fallon (2003), Reeder (2003) では, 個人の持つ性 
役割観の違いによって他者関係の質が異なることが示 されており，個人がどのような性役割観を持つかに よって, どの他者視点の理想一現実自己のズレが自尊 感情に影響を与えるかが異なると考えられる。そのた め, 本研究では複数の他者視点の理想一現実自己のズ レが自尊感情に与える影響が, 性役割観の違いによっ て異なるかどうかについても検討する。

また, 本研究では成人期を子育て期(就学前の子どもを 持つ群) と巣立ち期 (大学生の子どもを持つ群) に分けて捉 える。成人期において子育ては生活の中心となる重要 な出来事であり, 子どもは身近で重要な他者である。 子どもの誕生を期に夫婦関係は変化するとされ (小野 寺, 2005), 子どもの存在はこの時期の個人の生活そのも のや対人関係のあり方に大きな影響を与える。子ども の成長に伴って, 子どもから受ける影響はもちろん, その他の他者との関係も変化していくと思われる。西 田 (2000) では, 各発達段階によって, どの役割が適応 に影響するのかが異なることが指摘されており, 他者 視点の理想一現実自己のズレが自尊感情に及ほす影響 には世代差がみられると予想される。

さらに, 成人期以降の発達には, 年齢以外の要因も 多様に絡んでくるため個人差を含んだ視点が重要であ るとされる(伊藤, 1999)。そのため本研究では, 就業形 態の違いによって他者視点の理想一現実自己のズレが 自尊感情に及ほす影響が異なるのかについても比較検 討する。

以上, 本研究では複数の他者視点の理想一現実自己 のズレが自尊感情に及ぼす影響について検討すること を目的とし，以下の仮説を検証する。

仮説 1 男性は, 職場の人が望む理想一現実自己のズ レが自尊感情に影響するが, 女性は複数の他者が望む 理想一現実自己のズレが自尊感情に影響する。

仮説 2 性役割観の違いによって, 他者視点の理想 一現実自己のズレが自尊感情に及ほす影響が異なる。 そして,これらの仮説に加えて, 世代(子育て期と巣立
ち期), 就業形態で他者視点の理想一現実自己のズレが 自尊感情に及ほす影響に差があるかどうかについても 探索的に検討する。

\section{方法}

調査参加者 就学前もしくは大学生の子どもを持つ 成人期の男女 404 名 (男性 171 名, 女性 231 名, 不明 2 名。属 性の詳細は $\mathrm{T}$ ABLE 1 参照)。

調查方法 調查時期は, 2004 年 12 月〜 2005 年 4 月。 子育て期は, 就学前の子どもをもつ個人であり, 保育 園 (2 園) の保護者と小学校の入学前ガイダンスに参加 した保護者である。自宅で実施後, それぞれの園, 学 校で回収した (後者は, 入学前ガイダンス時に他の入学書類と 共に配布し,それらの書類の提出日に学校で回収した)。巣立ち 期は大学生の両親であり, 大学生を通じて配布, 回収 した。

質問紙の構成 (1)他者視点の理想自己の表出 理想 自己の表出は従来の理想自己を扱った研究（水間, 1998; 遠藤, 1992 ；杉山, 1995）を参考に作成した。水間（1998） に做い, 自由記述と研究者が与えた項目の選択 (理想自 己の例) の両方が可能な状況を設定して理想自己を表出 させる方法をとった。

理想自己は個人にとって重要なものでなければ自己 評価と関連しないことが指摘されている（Moretti \& Higgins, 1990 ; 遠藤, 1992)。この方法は, 内在的視点 (自 ら自己のあり方を対象化して理解する枠組み;溝上, 1999) と外 在的視点（第三者的な視点をもって個人の自己を理解する枠組 みの双方を組み入れ, 個人にとってょり重要な理想自 己を扱えると考えられる。この方法では各調查参加者 ごとに挙げられる内容が異なることになるが, 個人に とって重要かどうかという点において同質なものを扱 えると考えられる。また，この方法で抽出された理想 一現実自己のズレと自尊感情との間には有意な負の相 関がみられている (水間, 1998 ; 松岡, 2006)。

本研究で扱う他者としては, Higgins(1987)で想定さ

TABLE 1 調查参加者の属性

\begin{tabular}{|c|c|c|c|c|c|c|c|c|c|c|c|}
\hline \multirow{4}{*}{$\frac{\text { 性 }}{\text { 男 }}$} & \multirow{4}{*}{$\begin{array}{c}\text { 世代 } \\
\text { 子育て期 } \\
\text { 巣立ち期 }\end{array}$} & \multirow{3}{*}{$\frac{\text { 合計 }}{97}$} & \multicolumn{5}{|c|}{ 就業形態 } & & & \multirow{2}{*}{\multicolumn{2}{|c|}{$\begin{array}{c}\text { 末子の } \\
\text { 平均年齢 }(S D)\end{array}$}} \\
\hline & & & 常勤 & 非常勤 & 専業主婦 & 無職 & 未記入 & \multicolumn{2}{|c|}{ 平均年齢 $(S D)$} & & \\
\hline & & & 92 & 0 & 0 & 0 & 5 & 37.5 & $(5.0)$ & 4.1 & $(2.4)$ \\
\hline & & 74 & 69 & 0 & 0 & 0 & 5 & 51.0 & (3.9) & 18.0 & (3.1) \\
\hline \multirow[t]{3}{*}{ 女 } & 子育て期 & 139 & 30 & 58 & 46 & 1 & 4 & 34.6 & $(4.4)$ & 4.1 & $(2.5)$ \\
\hline & 巣立ち期 & 94 & 25 & 38 & 27 & 2 & 2 & 48.3 & (4.1) & 18.2 & (3.7) \\
\hline & 全体合計 & 404 & 216 & 96 & 73 & 3 & 16 & 41.4 & $(8.2)$ & 9.89 & (7.5) \\
\hline
\end{tabular}

注）子育て期は就学前の子どもを持つ群, 巣立ち期は大学生の子どもを持つ群である。 
れた重要な他者と, 従来の多重役割の研究を参考に, 子ども, 配偶者, 両親, 親しい友人, 職場の人の 5 者 を取り上げた(専業主婦の場合は職場の人を除く 4 者)。それ ぞれの他者ごとに，その他者から望まれているであろ う自分のイメージを 3 つずつ挙げるように求めた。教 示は以下の通りである。「あなたが○○(ここには, 5 つの 他者のどれかが入る) から『こうあって欲しい』と望まれ ていると思う自分のイメージを思い浮かべてください。 その理想の中身はどのようなものですか。以下の [ ] に自由に書いてください。 3 個全て書くようにしてく ださい。書きにくい方は, 別紙に挙げた例1の中から選 んでその言葉を記入していただいても構いません」。○ ○に入る他者を変えて, 1 人の調査参加者につき 5 つ の他者視点による理想自己をそれぞれ 3 つずつ表出さ せた（回答例：子ども視点の理想自己の場合：遊んでくれる自 分, いつも家にいてくれる自分, 優しい自分)。

\section{(2)各他者視点の理想一現実自己のズレの測定}

(1)で測定した他者視点の理想自己それぞれについて 現実自己との一致度を尋ねた。教示は以下の通り。「挙 げていただいた 3 つの理想の項目それぞれについて, 現在のあなた自身はどの程度当てはまっていますか」。 「非常に当てはまる(7)」から「全く当てはまらない(1)」 までの 7 件法。ズレはこれを逆転させた值となる。

(3)自尊感情尺度 山本・松井・山成（1982）による Rosenberg（1965）の邦訳版。10 項目。 5 件法。

理想自己の例は松岡（2006）と同様に, 水間 (1998), 遠藤 (1992) などを参考に, 山本ら（1982）によって示された自己 評価に関連する自己認知の諸側面 (社交, スポーツ能力, 知 性, 優しさ, 性, 容貌, 生き方, 経済力, 趣味や特技, まじめ さ, 学校の評判の 11 側面)を網羅するように考慮した。具体的 な内容を以下に示す。「容姿がよい自分, 健康状態がよい自分, 体力に自信がある自分, 明るい性格の自分, 思いやりのある自 分, 協調性 (人との関係がうまくやれること) のある自分, 積 極性（自分から進んで行動すること）のある自分, 知性がある 自分, まじめな自分, 気持ちがいつも安定している自分, 精神 的に大人な自分, 自分自身の生き方に自信を持つ自分, 責任感 がある自分, 指導力（リーダーとして人を引つ張る力）がある 自分, 忍耐力 (我慢する力) がある自分, 時間を守る自分, 要 領がよい自分, 好かれている自分, 服装の趣味がよい自分, 満 足のいく職業についている自分, 気に入った家に住める自分, 経済状態がよい自分, 社会的地位が高い自分, 社会の一員とし ての責任を果たせている自分, 仕事ができる自分, 親孝行な自 分, きょうだいの一員としての役割を果たせている自分, 子ど もに対して, 親としての責任を果たせている自分, 家族を大切 にする自分, 男らしい・女らしい自分, 過去の自分を受け入れ ている自分, 人生を楽しむ自分 (計 34 個)」。松岡 (2006) で は, 理想自己の例の語尾を「〜な人」としいたが, 本研究で はより自分に即して答えるように「〜な自分」という表現を用 いることとした。
(4)性役割観 平等主義的性役割態度スケール短縮版 (鈴木, 1994)，15 項目。5 件法。

(5)デモグラフィック変数 年齢, 性別, 就業形態(常 勤・非常勤 (パートタイムを含む)・専業主婦 (夫) - 無職), 子 どもの有無, 末子の年齢, 既婚か未婚かについて回答 を求めた。

\section{結果}

\section{1 . 他者視点の理想一現実自己のズレ得点の処理手続} き

水間（1998）の理想一現実自己のズレの算出方法に 倣って得点化した。自由記述で表出した他者視点の理 想自己それぞれについて求めた現実自己との一致度を 逆転させて合計し, 項目数で除した。これを他者視点 の理想一現実自己のズレ得点とした(各ズレ得点の信頼性 係数は, 子ども $\alpha=.67$, 配偶者 $\alpha=.74$, 両親 $\alpha=.68$, 友人 $\alpha=.80$, 職場の人 $\alpha=.77) 。 こ の$ 方法により, 5 つの他者 視点 (子ども, 配偶者, 両親, 友人, 職場) の理想一現実自己 のズレ得点を算出した。

なお, 就業形態別の分析については, 本研究の調査 参加者の男性が全て常勤職であったため, 女性のみを 対象に行った。就業形態別以外の分析については, 男 女の比較を可能にするため, 専業主婦は除いて有職の 男女のみを対象にして行った。（記述統計量は, 有職男女の 值を $\mathrm{T}_{\mathrm{ABLE}} 2$, 女性のみの就業形態別の值を $\mathrm{T}_{\mathrm{ABLE}} 3$ に記載)。

\section{2. 各变数の平均値の差について}

(1)他者視点の理想一現実自己のズレ得点の性, 世代 差 5つの他者視点の理想一現実自己のズレ得点の平 均值について性（男・女）×世代（子育て・巣立ち期）の二 要因分散分析を行った。

その結果, 職場視点の理想一現実自己のズレには有 意な差がみられず, その他の 4 つのズレ(子ども, 配偶者, 両親, 友人) において交互作用もしくは主効果がみられ た。子ども, 配偶者視点の理想一現実自己のズレは交 互作用が有意であったため（順に $F(1,304)=6.29$, $p<.05$ ：配偶者 $F(1,301)=4.62, p<.05)$, 単純主効果の検定 を行った。その結果, 子ども視点の理想一現実自己の ズレは, 子育て期においてのみ性差がみられ, 女性の 方が男性よりもズレが大きかったが $(F(1,304)=16.89$, $p<.001)$, 巣立ち期においては性差がみられなかった。 また，子育て期の女性の方が巣立ち期の女性よりもズ レが大きく $(F(1,304)=5.27, p<.05)$, 配偶者視点の理想 一現実自己のズレも同様に, 子育て期の女性の方が巣 立ち期の女性よりもズレが大きかった $(F(1,301)=15.21$, $p<.001)$ 。両親, 友人視点の理想一現実自己のズレは世 
TABLE 2 諸変数の平均值と $S D$ (有職男女)

\begin{tabular}{|c|c|c|c|c|c|c|c|c|}
\hline \multirow[b]{3}{*}{ 性 } & \multirow[b]{3}{*}{ 世代 } & \multicolumn{5}{|c|}{ 他者視点の理想－現実自己のズレ得点 } & \multirow[b]{2}{*}{ 自尊感情 } & \multirow[b]{2}{*}{ 性役割得点 } \\
\hline & & 子ども & 配偶者 & 両親 & 友人 & 職場 & & \\
\hline & & 平均値 $(S D)$ & 平均值 $(S D)$ & 平均値 $(S D)$ & 平均値 $(S D)$ & 平均値 $(S D)$ & 平均値 $(S D)$ & 平均值 $(S D)$ \\
\hline \multirow[t]{2}{*}{ 男 } & 子育て期 & $2.41(1.11)$ & $2.76(1.29)$ & $2.49(1.17)$ & $2.31(1.20)$ & $2.41(1.22)$ & $3.53(0.56)$ & $3.18(0.53)$ \\
\hline & 巣立ち期 & $2.58(0.95)$ & $2.52(0.99)$ & $2.20(1.00)$ & $2.23(1.02)$ & $2.21(1.01)$ & $3.83(0.57)$ & $3.19(0.63)$ \\
\hline \multirow[t]{2}{*}{ 女 } & 子育て期 & $3.08(1.10)$ & $3.05(1.36)$ & $2.69(1.14)$ & $2.45(1.18)$ & $2.38(1.14)$ & $3.39(0.70)$ & $3.62(0.51)$ \\
\hline & 巣立ち期 & $2.67(1.15)$ & $2.23(1.15)$ & $2.05(1.05)$ & $2.04(1.13)$ & $2.15(2.02)$ & $3.74(0.64)$ & $3.67(0.53)$ \\
\hline
\end{tabular}

注）性役割得点は，高いほど平等主義的であることを示す。

TABLE 3 就業形態別にみた諸変数の平均値と $S D$ (女性のみ)

\begin{tabular}{|c|c|c|c|c|c|c|c|c|}
\hline \multirow[b]{3}{*}{ 世代 } & \multirow[b]{3}{*}{ 就業形態 } & \multicolumn{5}{|c|}{ 他者視点の理想－現実自己のスレ得点 } & \multirow[b]{2}{*}{ 自尊感情 } & \multirow[b]{2}{*}{ 性役割得点 } \\
\hline & & 子ども & 配偶者 & 両親 & 友人 & 職場 & & \\
\hline & & 平均値 $(S D)$ & 平均値 $(S D)$ & 平均値 $(S D)$ & 平均値 $(S D)$ & 平均値 $(S D)$ & 平均値 $(S D)$ & 平均値 $(S D)$ \\
\hline \multirow[t]{3}{*}{ 子育て期 } & 常勤 & $3.09(0.78)$ & $2.96(1.13)$ & $2.48(0.87)$ & $2.25(1.03)$ & $2.30(1.01)$ & $3.52(0.76)$ & $3.86(0.46)$ \\
\hline & 非常勤 & $3.08(1.24)$ & $3.09(1.47)$ & $2.79(1.25)$ & $2.55(1.24)$ & $2.43(1.20)$ & $3.32(0.67)$ & $3.49(0.49)$ \\
\hline & 専業主婦 & $3.17(1.01)$ & $2.94(1.11)$ & $2.55(1.21)$ & $2.74(1.22)$ & $1 \quad 1$ & $3.30(0.60)$ & $3.39(0.47)$ \\
\hline \multirow[t]{3}{*}{ 宩立ち期 } & 常勤 & $2.59(1.06)$ & $2.16(1.09)$ & $1.93(0.98)$ & $2.15(0.96)$ & $1.76(0.75)$ & $3.88(0.66)$ & $3.86(0.54)$ \\
\hline & 非常勤 & $2.72(1.21)$ & $2.29(1.21)$ & $2.13(1.09)$ & $1.97(1.23)$ & $2.40(2.50)$ & $3.66(0.62)$ & $3.55(0.48)$ \\
\hline & 専業主婦 & $2.93(1.45)$ & $2.63(1.31)$ & $2.03(1.25)$ & $2.17(1.19)$ & $1 \quad 1$ & $3.60(0.63)$ & $3.70(0.52)$ \\
\hline
\end{tabular}

注） 性役割得点は, 高いほど平等主義的であることを示す。

代の主効果が有意, もしくは有意な傾向であり，いず れも子育て期の方が, 巣立ち期よりも大きかった順に $F(1.299)=10.87, p<.001 ; F(1,297)=3.29, .05<p<.1) 。$

これらの結果から，全体的に他者視点の理想一現実 自己のズレの值は, 子育て期の方が巣立ち期よりもズ レが大きい傾向があるといえる。これは, 理想一現実 自己のズレが年齢に伴って隇少していく傾向（松岡, 2006) と一致している。

就業形態の差 各ズレ得点を従属変数, 女性の就業 形態 (常勤, 非常勤, 専業主婦) を独立変数とした一要因分 散分析を行った。その結果，5つのズレ全てにおいて， 有意な差はみられなかった (なお, 職場視点の理想一現実自 己のズレ得点についての分析は, 専業主婦を除いて行った)。

(2)性役割観得点，自尊感情得点の性，世代差 平等 主義的性役割態度スケールについて, 計 15 項目の尺度 得点を合計し, 項目数で除した值を性役割観得点とし た $(\alpha=.87)$ 。この得点は高いほど平等主義的であること を示す。また, 自尊感情尺度についても 10 項目の尺度 得点を合計し, 項目数で除した值を自尊感情得点とし た $(\alpha=.83) 。$

性役割得点, 自尊感情得点について, 性 (男·女) $\times$ 世 代 (子育て・巣立ち期) の二要因分散分析を行った。その 結果, 性役割観得点は, 性の主効果のみ有意であり, 男性のほうが女性よりも伝統主義的であった（F
$(1,306)=52.12, p<.001)$ 。また, 自尊感情は世代の主効果 のみ有意であり, 子育て期よりも巣立ち期の方が有意 に高かった $(F(1,301)=19.1, p<.001) 。$

就業形態の差 女性の就業形態を独立変数に, 自尊 感情得点と性役割観得点を従属变数とした一要因分散 分析を行った。その結果, 自尊感情は常勤職女性の方 が, 専業主婦と比べて高い傾向にあり $(F(2,220)=$ $2.83, .05<p<.1)$, 性役割観得点は, 常勤職女性が, 非常 勤, 専業主婦と比べて有意に高かった $(F(2,222)=10.33$, $p<.001)$ 。

\section{3. 他者視点の理想一現実自己のズレが自尊感情に及 ぼす影響}

他者視点の理想一現実自己のズレが自尊感情に及ほ す影響について, 性, 世代, 性役割観の 3 要因から検 討するために以下の分析を行った。

まず，子育て・巣立ち期の男女を性役割観得点の平 均点を基準に上位群, 下位群に分け(前者が平等主義群, 後 者が伝統主義群となる), 性(男女) $\times$ 世代(子育て・巣立ち期 $) \times$ 性役割観（伝統主義・平等主義）の 8 群に分けた。

5 つの他者視点の理想一現実自己のズレ得点と自尊

2 各群の性役割観得点は伝統, 平等主義群の順に, 男性: 子育 て期 2.75( $S D .30), 3.58(S D .34)$, 巣立ち期 : $2.69(S D .41)$, $3.66(S D .38)$ 。女性：子育て期 $3.16(S D .31), 3.96(S D .30)$; 巣立ち期 $3.23(S D .30), 4.09(S D .32)$ 。 
感情との間に関連があるかを検討するために相関係数 を算出したところ, すべての群で少なくともどれか 1 つとは有意な負の相関がみられだ。そこで, 他者視点 の理想一現実自己のズレが自尊感情に及ほす影響につ いて検討するために，5つの理想一現実自己のズレを 説明変数, 自尊感情を基準変数とするステップワイズ 法による重回帰分析を行った $\left(\mathrm{T}_{\mathrm{ABLE}} 4\right)^{4}$ 。以下，得られ た結果について, 性, 性役割観, 世代に注目して順に 述べていく。

性差について(仮説 1) 男性は, 子育て期の平等主義 群以外の 3 群において, 職場視点の理想一現実自己の ズレ得点のみが自尊感情に影響していた。そして女性 は, 4 群全てにおいて 2 つの他者視点の理想一現実自 己のズレが自尊感情に影響している傾向がみられ，子 育て期の伝統主義群は両親と職場, 平等主義群は友人 と職場，巣立ち期の伝統主義群は子どもと両親，平等 主義群は子どもと友人が影響していた。この結果から, 男性は職場, 女性は複数の他者視点の理想一現実自己 のズレから影響を受けるだろうという仮説 1 は全体的 に支持されたといえる。

性役割観の違いによる差について（仮説 2) また， 巣立ち期の男性以外では, 性役割観の違いによって, 他者視点の理想一現実自己のズレが自尊感情に及ぼす 影響が異なっていた。子育て期の男性は, 伝統主義群 では職場のみが影響していたが，平等主義群では子ど もが影響していた。一方，女性では，両世代に共通し て, 性役割観による違いがみられ, 伝統主義群では両 親が，平等主義群では友人が影響していた（巣立ち期の 両親は有意傾向)。このことから, 仮説 2 は巣立ち期の男 性を除いて支持されたといえる。

世代差について 世代差に注目すると，男性は，さ きに述べたように, 性役割観による影響を受けるかど

3 説明変数間の相関係数は, 男性: 子育て期伝統主義群 $r=.486, p<.001 \sim r=.751, p<.001$, 平等主義群 $r=.155, n$. $s . \sim r=.591, p<.001$, 巣立ち期伝統主義群 $r=.206, n . s . \sim$ $r=.760, p<.001$, 平等主義群 $r=.376, p<.05 \sim r=.879$, $p<.001$ 。女性：子育て期伝統主義群 $r=.176, n . s . \sim$ $r=.661, p<.001$, 平等主義群 $r=.417, p<.01 \sim r=.634$, $p<.001$; 巣立ち期伝統主義群 $r=.038, n . s . \sim r=.693$, $p<.001$, 平等主義群 $r=.345, .05<p<.1 \sim r=.597, p<.001$ であった。

説明変数間に高い相関関係がみられたが, 多重共線性が生じ ている可能性を示すVIF の值は, 子育て期男性：伝統 1.00 , 平 等 1.00 , 女性: 伝統 1.37 , 平等 1.23 , 巣立ち期男性: 伝統 1.00 , 平等 1.00 , 女性 : 伝統 1.25 , 平等 1.45 であった。この ため, 多重共線性が生じている可能性は低いと考え, 全ての説 明変数を投入して重回帰分析を行った。
うかという点で，世代差がみられた。一方，女性は性 役割観が影響するという点は両世代共通であったが, 職場と子どもの影響は世代間で大きく異なっており， 職場の影響は子育て期のみ, 子どもの影響は巣立ち期 のみでみられた。

就業形態の差について さらに, 女性のみを対象と して就業形態によって他者視点の理想一現実自己のズ レが自尊感情に与える影響が異なるかを検討した (TABLE 5)。これまでの分析と同様に 5 つの他者視点の 理想一現実自己のズレを説明変数（専業主婦は, 職場を除 く 4 つ), 自尊感情を基準変数にした重回㷌分析 (ステッ プワイズ法) を行った。

その結果, 就業形態によって他者視点の理想一現実 自己のズレが自尊感情に及ぼす影響は異なっていた。 両世代に共通して, 専業主婦では両親のみの影響がみ られ，常勤職では両親と職場が影響していた。非常勤 職では, 世代差が大きく, 常勤職, 専業主婦でみられ たような両世代共通して自尊感情に影響している他者 視点の理想一現実自己のズレは見出せなかった。ただ し, 常勤職と比較した場合には, 両世代ともに両親の 影響がないことが共通していた。

また，以上全ての分析において，配偶者視点の理想 一現実自己のズレの影響はみられなかった。

\section{考察}

本研究では, 成人期を対象に他者視点の理想一現実 自己のズレが自尊感情に与える影響について, 性, 性 役割観，世代，就業形態の差を考慮して検討した。本 研究の結果から, 男性は 4 群中 3 群において職場視点 の理想一現実自己のズレのみが自尊感情へ影響し, 女 性は全ての群で子ども, 両親, 友人のうち, 2 者の他 者視点の理想一現実自己のズレが自尊感情に影響して いた。この結果は, 従来の研究において男性が職場, 女性が複数の役割を重視する傾向と合致するものであ り，仮説 1 は支持されたといえる。

川浦・池田・伊藤・本田（1996）では, 男性のソーシャ ルサポートのネットワークが女性と比べて狭く, 家庭 外では職場仲間に限られているが, 女性は配偶者, 子 どもの他に親や兄弟，友人をサポート対象に組み込ん でいることが示されている。本研究の結果からも男性 が影響を受ける他者視点の理想一現実自己のズレが職 場に限定されている様子がうかがえた。

男性における他者視点の理想自己の内容をみると, 職場以外の 4 つの他者, とりわけ子ども, 配偶者視点 の理想自己においても, 仕事の達成と関わるようなも 
TABLE 4 自尊感情を基準変数にした重回帰分析結果（ステップワイズ法）

\begin{tabular}{|c|c|c|c|c|}
\hline \multirow[b]{3}{*}{$\begin{array}{c}\text { 他者視点の } \\
\text { 理想一現実自己のズレ }\end{array}$} & \multicolumn{4}{|c|}{ 男性 } \\
\hline & \multicolumn{2}{|c|}{ 子育て期 } & \multicolumn{2}{|c|}{ 巣立ち期 } \\
\hline & $\begin{array}{c}\text { 伝統主義群 } \\
n=44\end{array}$ & $\begin{array}{c}\text { 平等主義群 } \\
n=48\end{array}$ & $\begin{array}{c}\text { 伝統主義群 } \\
n=31\end{array}$ & $\begin{array}{c}\text { 平等主義群 } \\
n=34\end{array}$ \\
\hline 子ども & - & $-.299^{*}$ & - & - \\
\hline 配偶者 & - & - & - & - \\
\hline 両親 & - & - & - & - \\
\hline 友人 & - & - & - & - \\
\hline 職場 & $-.339^{*}$ & - & $-.588^{* * *}$ & $-.541^{* * *}$ \\
\hline$R^{2}$ & $.115^{* * *}$ & $.089^{*}$ & $.346^{* * *}$ & $.293^{* * *}$ \\
\hline \multirow[t]{3}{*}{ 調整済み $R^{2}$} & .094 & .069 & .321 & .271 \\
\hline & \multicolumn{4}{|c|}{ 女性(有職女性のみ) } \\
\hline & \multicolumn{2}{|c|}{ 子育て期 } & \multicolumn{2}{|c|}{ 巣立ち期 } \\
\hline $\begin{array}{c}\text { 他者視点の } \\
\text { 理想一現実自己のズレ }\end{array}$ & $\begin{array}{c}\text { 伝統主義群 } \\
n=39\end{array}$ & $\begin{array}{c}\text { 平等主義群 } \\
n=49\end{array}$ & $\begin{array}{c}\text { 伝統主義群 } \\
\quad n=31\end{array}$ & $\begin{array}{c}\text { 平等主義群 } \\
n=31\end{array}$ \\
\hline 子ども & - & - & $-.526^{* * *}$ & $-.514^{* *}$ \\
\hline 配偶者 & - & - & - & - \\
\hline 両親 & $-.290^{*}$ & - & $-.292^{\dagger}$ & - \\
\hline 友人 & - & $-.288^{*}$ & - & $-.325^{*}$ \\
\hline 職場 & $-.554^{* * *}$ & $-.418^{* *}$ & - & - \\
\hline$R^{2}$ & $.576^{* * *}$ & $.390^{* * *}$ & $.506^{* * *}$ & $.482^{* * *}$ \\
\hline 調整済み $R^{2}$ & .552 & .363 & .468 & .442 \\
\hline
\end{tabular}

TABLE 5 就業形態別（女性）自尊感情を基準変数にした重回帰分析結果（ステップワイズ法）

\begin{tabular}{|c|c|c|c|c|c|c|}
\hline \multirow[b]{3}{*}{ 他者視点の } & \multicolumn{6}{|c|}{ 就業形態別 女性のみ } \\
\hline & \multicolumn{3}{|c|}{ 子育て期 } & \multicolumn{3}{|c|}{ 巣立ち期 } \\
\hline & 常勤 & 非常勤 & 専業主婦 & 常勤 & 非常勤 & 専業主婦 \\
\hline 理想－現実自己のズレ & $n=30$ & $n=58$ & $n=46$ & $n=25$ & $n=38$ & $n=27$ \\
\hline 子ども & - & - & & $-.364^{*}$ & $-.565^{* * *}$ & - \\
\hline 配偶者 & - & - & - & - & - & - \\
\hline 両親 & $-.559^{* * *}$ & - & $-.432^{* *}$ & $-.363^{*}$ & - & $-.487^{*}$ \\
\hline 友人 & - & $-.314^{*}$ & - & - & - & - \\
\hline 職場 & $-.357^{*}$ & $-.451^{* * *}$ & ノ & $-.355^{* *}$ & - & ノ \\
\hline$R^{2}$ & $.663^{* * *}$ & $.468^{* * *}$ & $.186^{* *}$ & $.722^{* * *}$ & $.320^{* * *}$ & $.237^{*}$ \\
\hline 調整済み $R^{2}$ & .637 & .449 & .167 & .680 & .298 & .203 \\
\hline
\end{tabular}

注）専業主婦は職場視点の理想一現実自己のズレを除いて分析を行った。

の「仕事がよくできる」,「経済状態がよい」，などの記 述が多くみられ, 特に巣立ち期の男性で多かった。こ のことは, 男性にとって職場での達成が職場以外の他 者からの期待に応えることにもつながり, 逆に言えば, 職場での失敗はそれ以外の他者関係にもネガティブな 影響を及ぽ可能性を示唆するといえる。近年, 成人 期の男性の経済・生活問題を苦にした自殺者の増加が 問題となっており (警察庁, 2005), このような現状は, 現代の男性性に偏った社会化が男性の人間としての可
能性を制限している，との認識が現れている(杉村, 1995)。男性にとって職場の存在は大きく，仕事におけ る達成が適応を左右する大きな要因となっていると考 えられる。

しかしながら，本研究では性役割観の違いによって 他者視点の理想一現実自己のズレが自尊感情に与える 影響が異なる傾向がみられ, 男性の子育て期の平等主 義群では子どもが影響していた。

仕事から受ける影響が非常に大きい男性にとって, 
妻子との関係は仕事上のストレスを緩衝するために非 常に重要なサポート源とされ(川浦ら, 1996), 父親が育 児に関心を持つことが母親と子どもにポジティブな影 響を与えるとされる（加藤・石井・牧野・土屋, $2002 ；$ 小野 寺, 2005)。男性自身とその家族の適応を考える上で, 男 性が職場以外にも関心を向けることは重要であるとい える。子育て期は，子どもができて家庭への関与が高 まり（柏木, 2003)，性役割観がより意識される時期であ るとされる。本研究では, 巣立ち期においては性役割 観による差がみられなかった。そのため, 子育てに多 く関わることが影響して子育て期のみで性役割観の違 いが現れた可能性も指摘できる。しかしながら，近年 の男性は, 徐々に仕事中心の自律・達成に偏った生き 方から脱却しつつあることが指摘されており（杉村， 1995), 本研究の結果は現代の男性における変化が現れ たものとして捉えられるかもしれない。

一方，女性は全ての群で 2 者の他者視点の理想一現 実自己のズレが自尊感情に影響しており，全体的に男 性と比べて複数の他者から影響を受けることが示され た。そして，影響を受ける他者の種類は性役割観，世 代, 就業形態によって異なっていた。

特徵的であったのは, 世代間で子どもと職場の影響 に顕著な差がみられたこと, 性役割観の違いによって 両親と友人の影響が異なっていたこと，専業主婦は世 代にかかわらず両親のみが影響していたこと，常勤職 では両親と職場が影響していたがそれと比較して非常 勤職では両親の影響がみられなかったこと, などが挙 げられる。

まず世代差について述べると, 子どもと職場の影響 が子育て期と巣立ち期では顕著に異なっており, 子ど も視点の理想一現実自己のズレは, 巣立ち期のみ, 職 場は逆に子育て期のみで影響していた。発達段階に よって, 母役割, 勤労者役割などの役割達成感は異な り, 適応との関連も変化するとされる (西田, 2000)。本 研究の結果は, 子育て期と巣立ち期で子ども, 職場か ら受ける影響が変化することを示していると考えられ る。

子育て期の女性における職場視点の理想自己の記述 内容をみると,「仕事ができる」,「責任感がある」,「指 導力がある, などが多くみられた。この時期は, 子ど もがまだ小さい中でも，責任をもって仕事をこなさな ければならないと考えられ，その葛藤が反映されてい ると思われる。一方, 巣立ち期になると仕事場での地 位や役割が安定し, 自尊感情への影響が他の他者視点 の理想一現実自己のズレと比較して相対的に小さくな
るのかもしれない。また，子ども視点の理想自己の内 容をみると子育て期は「一緒に遊ぶ」,「怒らない」な ど，子どもとの関わり方に関するものが多いが，巣立 ち期には「人生を楽しむ」など自分自身の生き方を表 す内容が挙げられていた。本研究における巣立ち期の 調査対象者は, 大学生の子どもがいる個人である。青 年は自分の家族に対して批判的な目をもち（茂木 1996), 親の結婚生活を見て, 自分の将来への手がかり にしているとされる (諸井, 1997)。巣立ち期はアイデン ティティの再体制化が行われる時期とされ（岡本 1997)，自身の生き方を問い直す上で，子どもからの視 点が意識されやすいのかもしれない。

次に, 性役割観の違いについて述べると, 男性の子 育て期では，性役割観の違いは職場と子どもの影響の 違いに現れていたが, 女性では両親と友人の影響に差 がみられ，両世代ともに伝統主義群では両親，平等主 義群では友人が影響していた。そして，女性のみを対 象に行った就業形態別の分析では, 専業主婦では両世 代共通に両親の影響のみが影響していた。

女性は男性と比較して青年期以後も親子関係が親密 であり (北村·無藤, 2003)，親を「困ったときに相談する」 サポート対象として選択する割合が高いとされる（川 浦ら, 1996)。とりわけ専業主婦は有職女性と比べてソー シャルネットワークが狭く，母親との結びつきが強い ことが指摘されている(北村·無藤, 2001)。専業主婦は伝 統主義的な就業形態であると思われ，本研究の結果か ら, 伝統主義的な価値観, 就業形態をもつ女性にとつ て両親の影響が他の他者よりも相対的に大きく, 一方, 平等主義群では両親よりも友人の影響があることが示 唆されたといえる。しかしながら, 伝統主義, 平等主 義の個人の両親, 友人との関係が具体的にどのような 側面で異なるのかについて，本研究では検討しきれて いない。そのため今後さらに詳細な検討が必要である。

また, 常勤職の女性と非常勤職の女性を比較すると, 前者は職場と両親の影響がみられたが, 後者では世代 にかかわらず両親の影響がみられなかった。女性は男 性と比較して結婚後も親子関係が親密であることはす でに述べたが, 常勤職の女性は, 仕事と家庭を両立す るために両親に頼ることが多いが, 非常勤職は常勤職 と比べると時間的余裕があり, 両親に面倒をかけるこ とが少ないのかもしれない。

しかしながら, 本研究では, 就業形態について, 大 まかなカテゴリーで分けただけであり, 非常勤職は, 仕事内容や労働時間がほほ常勤職に近いものから, 週 に 1 日，数時間でよい勤務など多様なものを含んでい 
る可能性がある。また, 男性の常勤職であっても, ど のような職種であるのか (チームワーク重視のものか, それ とも個人の独立性が高い仕事かどうか), 職場での立場の違 い(リーダー的な立場にあるか否か)などによって，職場に おける他者の影響が大きく異なると考えられる。今後, 職場の性質の違いについての検討が求められる。

さらに, 本研究の結果では, 全ての群において配偶 者視点の理想一現実自己のズレの影響はみられなかっ た。成人期の心理的適応に夫婦関係が大きな影響を及 ほすことは従来から指摘されているが（伊藤・池田・川浦, 1999)，親役割や職業役割に比べて配偶者役割の影響力 が小さい（北村, 無藤, 2003 ; 伊藤, 1999）ともいわれている。 小野寺 (2005) では, 妻は親になってから徐々に夫に対 して頑固になることが示されており，配偶者視点の理 想自己から現実自己がズレていても，それは自尊感情 を下げるような性質ではないのかもしれない。

以上のように, 本研究では他者視点の理想一現実自 己のズレが自尊感情に及ほすす影響について検討した。 全体的には男性は職場, 女性は複数の他者視点の理想 一現実自己のズレが自尊感情に影響するが，男性で あっても子育て期の平等主義では職場ではなく子ども からの影響がみられ，女性であっても専業主婦では両 親のみの影響がみられるなど，性役割観，就業形態， 世代によって異なることが示された。

男性は全体的に職場のみ, 専業主婦は両親のみから 影響を受ける傾向は，伝統的な価值観，就業形態が限 定的な他者関係と結びついていることを示唆している ように思える。近年，伝統主義が行き詰まりを見せて おり,ソーシャルネットワークの狭さは適応状態を損 なうこと (北村, 無藤, 2003), 一つの役割にのみ従事しす ぎることは, 退職による危機や空の巣症候群を引き起 こしやすいことが示唆される (e.g., 岡本, 1997)。これら のことから，成人期の個人の適応を考える上で，幅広 い他者関係を築く必要性が指摘できると思われる。本 研究では, 性役割観, 就業形態の違いによって, 他者 視点の理想一現実自己のズレが自尊感情に及ぼす影響 が異なっていた。幅広い他者関係を築くために具体的 にどうしたらよいかという問題は困難であるが, 従来 の研究や本研究の結果を踏まえて考えると，それには 限定された伝統的な価値観や就業形態からの脱却が一 つの鍵となるのではないか, と思われる。

\section{引用文献}

Banikiotes, P.G., Neimeyer, G.J., \& Lepkowsky, C. 1981 Gender and sex-role orientation effects on friendship choice. Personality and Social Psychology Bulletin, 7, 605-610.

Donaghue, N., \& Fallon, B.J. 2003 Gender-role self-stereotyping and the relationship between equity and satisfaction in close relationships. Sex Roles, 48, 217-230.

遠藤辰雄・井上祥冶・蘭 千壽 1992 セルフ・エス ティームの心理学一自己価値の探求一 ナカニシ ヤ出版

遠藤由美 1992 自己評価基準としての負の理想自己 心理学研究, 63, 214-217. (Endo, Y. 1992 Negative ideal-self as a standard of self -esteem. Japanese Journal of Psychology, 63, 214-217.)

福島 治 2003 自己知識の多面性と対人関係 社会 心理学研究, 18, 67-77. (Fukushima, O. 2003 Multiple forms of self-knowledge and interpersonal relationships. Japanese Journal of Social Psychology, 18, 67-77. )

Helson, R., Elliot, T., \& Leigh, J. 1990 Number and quality of roles: A longitudinal personality view. Psychology of Women Quarterly, 14, 83-101.

Higgins, E.T. 1987 Self-discrepancy : A theory relating self and affect. Psychological Review, 94, 319-340.

Higgins, E.T., Klein, R., \& Strauman, T. 1985 Self-concept discrepancy theory : A psychological model for distinguishing among different aspects of depression and anxiety. Social Cognition, 3, 51-76.

稲毛教子 1996 固定的性別役割分担意識の分析 人 間社会学部編 東京国際大学論叢, 53, 161-175.

伊藤美奈子 1999 個人と社会という観点からみた成 人期女性の発達 岡本祐子(編) 女性の生涯 発 達とアイデンティティ一個としての発達・関わり の中での成熟— 北大路書房 Pp. 87-112.

伊藤裕子・池田政子・川浦康至 1999 既婚者の疎外 感に及ほす夫婦関係と社会的活動の影響 心理学 研究, 70, 17-23. (Ito, Y., Ikeda, M., \& Kawaura, Y. 1999 The effects of marital communication and social activity on alienation in married women and men. Japanese Journal of Psychology, 70, 17-23.)

Josselson, R.L. 1973 Psychodynamic aspects of 
identity formation in college women. Journal of Youth and Adolescence, 2, 3-52.

梶田硁一 1988 自己意識の心理学 東京大学出版会 柏木惠子 2003 家族心理学一社会変動・発達・ジェ ンダーの視点一 東京大学出版会

加藤邦子・石井クンツ昌子・牧野カツコ・土谷みち子 2002 父親の育児かかわり及び母親の育児不安が 3 歳児の社会性に及ぼす影響：社会的背景の異な る 2 つのコホート比較から 発達心理学研究, 13, 30-41. (Kato, K., Ishii-Kuntz, M., Makino, K., \& Tsuchiya, M. 2002 The impact of paternal involvement and maternal childcare anxiety on sociability of three-year-olds : Two-cohort comparison. Journal of Developmental Psychology, 13, 30-41.)

川浦康至・池田政子・伊藤裕子・本田時雄 1996 既 婚者のソーシャルネットワークとソーシャルサ ポート一女性を中心に 心理学研究, 67, 333-339. (Kawaura, Y., Ikeda, M., Ito, Y., \& Honda, T. 1996 Social network and social support for married women and their spouses. Japanese Journal of Psychology, 67, 333-339.)

警察庁 2005 平成 16 年度における自殺の概要資料 北村琴美・無藤 隆 2001 成人の娘の心理的適応と 母娘関係一娘の結婚・出産というライフイベント に着目して一発達心理学研究，12，46-57. (Kitamura, K., \& Muto, T. 2001 The influence of adult mother-daughter relationships on daughters' psychological well-being : Life events of marriage and childbearing. Japanese Journal of Developmental Psychology, 12, 46-57.)

北村琴美・無藤 隆 2003 中年期女性が報告する娘 との関係と心理的適応との関連 心理学研究, 74, 9-18. (Kitamura, K., \& Muto, T. 2003 Adult mother-daughter relationship and mother's psychological well-being. Japanese Journal of Psychology, 74, 9-18.)

前川あさ美・無藤清子・野村法子・園田雅代 1996 複

数役割を持つ成人期女性の葛藤と統合プロセス 東京女子大学女性学研究所

松岡弥玲 2006 理想自己の生涯発達一変化の意味と 調節過程を捉える一 教育心理学研究, 54, 45-54. (Matsuoka, M. 2006 Ideal self across the life span : Roles and regulation process. Japanese
Journal of Educational Psychology, 54, 45-54.) 溝上慎一 1999 自己の基礎理論 金子書房 水間玲子 1998 理想自己と自己評価及び自己形成意 識の関連について 教育心理学研究, 46, 131-141. (Mizuma, R. 1998 A study of relationship between an ideal self and self-esteem, and consciousness to self-formation. Japanese Journal of Educational Psychology, 46, 131-141.)

Moretti, M. M., \& Higgins, E. T. 1990 Relating self-discrepancy to self-esteem : The contribution of discrepancy beyond actual-self ratings. Journal of Experimental Social Psychology, 26, 108-123.

諸井克英 1997 子どもの眼からみた家族内労働の分 担の衡平性:女子青年の場合 家族心理学研究, 11, 69-81. (Moroi, K. 1996 How do adolescent females perceive their equity in the division household labor ? Japanese Journal of Family Psychology, 11, 69-81.)

茂木千明 1996 家族の健康性に関する一研究：大学 生の子どもの視点から 家族心理学研究, 10, 47-62. (Motegi, C. 1996 A study on the healthy family. Japanese Journal of Family Psychology, 10, 47-62.)

西田由紀子 2000 成人女性の多様なライフスタイル と心理的 well-being に関する研究, 48，433-443. (Nishita, Y. 2000 Diverse life-styles and psychological well-being in adult women. Japanese Journal of Educational Psychology, 48, 433-443.)

小川千穂 2003 特定のストレスフルな出来事が勤労 者の精神的健康に及ほす影響一ライフ・イベント， ストレスへの認知およびコーピングとの関連一 健康心理学研究, 16(2), 44-52. (Ogawa, C. 2003 The impact of a specific stressful event on the mental health of workers. Japanese Journal of Health Psychology, 16(2), 44-52.)

岡本祐子 1995 人生半ばを越える心理 無藤 隆他

編 講座生涯発達心理学 5 一老いることの意味 第 2 章 金子書房 Pp. 41-80.

岡本祐子 1997 中年からのアイデンティティ発達の 心理学 ナカニシヤ出版

小野寺敦子 2005 親になることにともなう夫婦関係

の変化 発達心理学研究, 16, 15-25. (Onodera, A. 2005 Marital changes during the transi- 
tion to parenthood. Journal of Developmental Psychology, 16, 15-25.)

太田さつき 2000 多重役割への従事とその結果一研 究の現状と今後の方向性一 青山学院大学教育学 会紀要教育研究, 44, 119-134.

Reeder, H. M. 2003 The effect of gender role orientaion on same- and cross-sex friendship formation. Sex Roles, 49, 143-152.

Reid, A., \& Deaux, K. 1996 Relationship between social and personal identities: Segregation or integration ? Journal of Personality and Social Psychology, 71, 1084-1091.

Rosenberg, M. 1965 Society and the adolescent self-image. Princeton, NJ : Princeton University Press.

杉村和美 1995 ライフサイクル 南 博文・やまだ ようこ(編) 講座生涯発達心理学 5 老いること の意味 金子書房 Pp. 117-152.

杉村和美 1999 現代女性の青年期から中年期までの アイデンティティ発達 岡本祐子(編) 女性の生 涯発達とアイデンティティ一個としての発達・関 わりの中での成熟— 北大路書房 Pp. 55-86.

杉山 成 1995 時間次元における諸自己像の関連か らみた時間的展望 心理学研究， 66, 283-287. (Sugiyama, S. 1995 A study of time perspective in relation to time-referent self-images. Japanese Journal of Psychology, 66, 283-287.)

鈴木淳子 1994 平等主義的性役割態度スケール短縮 版 (SESRA-S) の作成 心理学研究, 65, 34-41. (Suzuki, A. 1994 Construction of the Scale of
Egalitarian Sex Role Attitudes (SESRA-S). Japanese Journal of Psychology, 65, 34-41. )

塚田美保 2000 性役割観に関する若者世代意見と親 世代意見の分布認知 心理学研究, 70, 6, 503-509. (Tsukada, M. 2000 Perceived distributions of opinions in young generation and their parents' generation regarding sex roles. Japanese Journal of Psychology, 70, 503-509.)

山田 康 2004 社会の変化と中高年の心の危機(1) 小此木啓吾・濱田庸子・山田 康〈次世代を育む 心〉の危機一ジェネラティビティ・クライシスを めぐって一 第 4 章 慶應義塾大学出版会 $\mathrm{Pp}$. 107-137.

山本眞理子・松井 豊・山成由紀子 1982 認知され た自己の諸側面の構造 教育心理学研究, $\mathbf{3 0}$, 64-68. (Yamamoto, M., Matsui, Y., \& Yamanari, Y. 1982 The structure of perceived aspects of self. Japanese Journal of Educational Psychology, 30, 64-68.)

\section{謝辞}

本研究は, 名古屋大学教育学部の心理行動科学実験 演習 II で実施した調査を基盤とし, 追加調査, 再分析 したものである。丁寧なご指導とご助言を下さった名 古屋大学教育発達科学研究科の高井次郎先生, 元吉忠 寛先生, ならびに名古屋大学教育発達科学研究科の大 学院生の皆様, 名古屋大学教育学部の学生の皆様に深 く感謝いたします。さらに貴重な時間を割いて調査に 参加して下さった皆様に心から御礼申し上げます。

(2005.7.8 受稿, ’06.5.20 受理) 


\section{Discrepancies Between Actual and Ideal Selves Desired by Significant Others and Self-Esteem in Adults : Perspectives on Gender Roles}

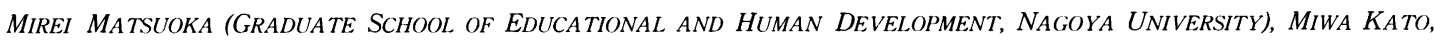
Mika Kanbe, YoKo SaWamoto, MachiKo Sugano, RikaKo TaKuma, YuKIE Mori (SChool of Education, NaGoYa UNIVERSITY) AND SAORI NOSE (FACULTY OF MEDICINE, TOYAMA UNIVERSITY)

JAPANESE JOURNAL OF EDUCATIONAL PSYCHOLOGY, 2006, 54, 522-533

The present study investigated the effects of discrepancies between actual and ideal selves desired by significant others (i.e., children, spouse, parents, peers, and co-workers) on several aspects of self-esteem, in relation to the moderator variables of gender, gender roles, developmental stage, and life style. Adult Japanese $(N=404$; average age, 41.4 years) who were parents of infants or adolescents completed a questionnaire. The results showed that the effect of discrepancies between actual and ideal selves desired by significant others was moderated by gender, gender roles, generation, and occupation. The ideal self desired by the male participants' co-workers strongly predicted the participants' self-esteem, whereas the ideal selves desired by several significant others (i.e., children, peers, and parents) predicted the self-esteem of the female participants. The ideal self desired by co-workers strongly predicted the self-esteem of the male participants with traditional gender attitudes, whereas the ideal self desired by their children predicted the self-esteem of the fathers of infants. The ideal self desired by their parents predicted the self-esteem of females with traditional gender role attitudes, whereas the ideal self desired by their peers predicted the self-esteem of gender egalitarians. In addition, the ideal self desired by housewives' parents predicted their self-esteem.

Key Words : ideal selves desired by significant others, gender, gender roles, self-esteem, adults 